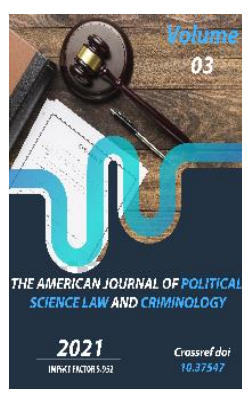

\title{
The Improvement Of Exploiting Public Assistance In Investigator'S Crime Prevention Activities
}

\author{
Khushvaktova Nodira Akramovna \\ Academy Of The MIA Of The Republic Of Uzbekistan
}

Copyright: Original content from this work may be used under the terms of the creative commons attributes 4.0 licence.

\section{ABSTRACT}

The article canvasses the role and importance of public participation in investigator's crime prevention activities, and the proposals for exploiting the general public in these activities are developed. Moreover, it clarifies the role of the citizen in preventing or disclosuring the crime, and its importance in pre-trial proceedings, the system of encouraging on the basis of the investigator's recommendation for his/her superior consciousness, courage, exemplary performance of social duty is thoroughly analyzed.

\section{KEYWORDS}

Public, investigator, submission, condicting the case pre-trial, encouraging norms, crime prevention.

\section{INTRODUCTION}

14 percentages more crimes were registered than in the same period last year in the 12 months of 2020, according to the data of the Ministry of internal affairs of the Republic of
Uzbekistan [1]. The increase of crime commission was observed in all administrative territorial units of the Republic. 
This, in sequance, requires law enforcement organs to increase the effeciency of preventive affairs. Improving the quality of preventive affairs can be accomplished through the direct involvement of the general public in these activities. This issue is at the center of attention not only of our country, but also of the international community.

In particular, the adoption of the Doha Declaration on ensuring public participation in conduct of the crime prevention and justice at the XIII Congress of the United Nations Organization in Doha on April 12-19, 2015 determines the importance of this issue.

It was mentioned that measures should be taken to ensure the participation of civil society to support the development of processes aimed at involving all members of society in this area, to perform propagation among the general public and support for the development of processes with the aim of activating public participation, as well as to increase the objectivity and effectiveness of such strategies, in order to increase the efficiency of efforts to prevent crime and increase public beliefs in law enforcement bodies were emphasized.

The Article 121 of the Constitution of the Republic of Uzbekistan also stipulates that public organizations and citizens may assist law enforcement bodies in protecting the rule of law, public order, the rights and freedoms of citizens [3, p. 67]. Undoubtedly, the successful fight against crime cannot be imagined without the application of preventive measures that can lead to crime. This requires that the person conducting the criminal investigation have an impartial and comprehensive knowledge of the reasons for the crime. Therefore, it is obvious that the preventive functions of the investigator do not end with the criminal-legal tasks of general and special prevention, which are solved in the framework of the quality investigation of the criminal case.

In this regard, it is incumbent upon the investigator to take other preventive and auxiliary-characterized measures to assist in the investigation of the criminal case: to make submission to eliminate the causes and conditions of the crime commission, conduct individual interviews, interact with the mass media and the public and so forth [4].

The following are reflected in connection with the cooperation of public associations and communities with their governing bodies in the preventive activities of the investigator and interrogator in the Criminal procedural code:

- The interrogator and investigator determine the causes of the crime and the circumstances that led to its commission, and take measures to eliminate these causes and conditions to the relevant state organ, citizens' self-government body, public association, community or authoritative official by submission of the review application during the investigative action of the criminal case (Article 297 of the $(P C)$;

- There are the stipulation on the possibility of submission of recommendation to the chiefs of the relevant enterprise, establishment and organization on the basis of the investigator's initiative about the citizen's superior consciousness, courage, exemplary performance of social duty in preventing or disclosuring the crime (Article 300 of the CPC).

We firmly believe that it is expedient to use not only imperative, but also incentive methods in 
ensuring the active participation of the public in the pre-trial phase of criminal proceedings. Particularly, the second type of submission is a submission by the interrogator, investigator or prosecutor to the Chief of the relevant enterprise, establishment or organization and the community about the citizen's superior consciousness, courage, exemplary performance of social duty in preventing or disclosuring the crime. The first time such an incentive norm was introduced in the current criminal procedural legislation. It aims to encourage citizens to be active in crime prevention and detection. Unfortunately, such submission is rarely introduced in practice [5, 484-485 6].

In this regard, inadequate application and ineffectiveness of incentive norms and measures of public influence, insufficient of legal mechanisms for crime prevention and detection, as well as instilling in citizens high legal culture and respect for the law are indicated as shortcomings and problems in judicial practice in the Decree of the President of the Republic of Uzbekistan "On measures to radically improve the system of criminal and criminal procedural legislation" dated on May 14, 2018 № PD-3723 [6].

Furthermore, the consideration of assessment of crime and crime prevention as the sole responsibility of law enforcement bodies, the ineffectiveness of identifying the causes and conditions of systematic occurrence of offenses and the futility of the development of measures aimed at an attempt to yield to elimination does Not provide the expected results as indicated in the Decree of the President of the Republic of Uzbekistan dated on March 14, 2017 № PD-2833 “On measures to further improve the system of crime prevention and fight against crime". It is necessary to improve the mechanisms for involving citizens and public organizations in crime prevention, including through financial and other incentives to address these shortcomings [7].

In our opinion, our laws and legal documents set norms for the use of general public in the pre-trial investigative actions, and as a result of their proper application, we can incentivize citizens and public organizations to actively participate in the conduct of pre-trial phase.

For instance, the rule to award with the letter of appreciation, commemorative gifts and cash prizes for the active participation and direct implementation of propaganda activities among citizens and public organizations in the prevention of crime and the fight against crime, the implementation of proposals and initiatives to address the causes of crime and the conditions that allow it is reflected in the Resolution of the Cabinet of Ministers of the Republic of Uzbekistan dated on January 8, 2018 № 15 “On approval of the Regulation on the procedure for incentives of citizens and public organizations for active participation in crime prevention and fight against crime" [8].

Likewise, special attention is paid to ensuring public participation not only through pre-trial proceedings, but also through incentives at the trial stage.

Notably, courts should introduce the practice of sending notices to the place of work, study or residence, as well as the use of the mass media in order to incentivize the citizens to prevent or stop offenses, the attempts to catch criminals and so forth are thoroughly indicated in the Resolution of the Plenum of the Supreme Court dated on December 19, 
2020 № 34 "On increasing the role of courts in determining the causes of crime and the conditions that led to their commission" [9].

It is expedient to financially support and ensure the safety of the persons assisting law enforcement bodies in maintaining legitimacy and order, protection of the rights and freedoms of citizens, to involve the general public extensively in the processes of crime prevention and fighting against them are of paramount importance [10, p. 144].

We believe that the prevalent use of this opportunity by the pre-trial organs conducting the criminal case will effectively strengthen the cooperation between law enforcement bodies and the public, as well as the prevention of crimes that are the decisive purpose.

The President Shavkat Mirziyoyev fittingly states that: "In present, the effectiveness of our reforms depends in many respects on four important factors - to provide the rule of law, to ruthlessly fight against corruption, to increase institutional capacity and to form strong democratic institutions" [11].

\section{REFERENCES}

1. Statistical data analyses of the Ministry of internal affairs.

2. Doha Declaration on integrating crime prevention and criminal justice into the broader United Nations agenda to address social and ecoNomic challenges and promote the rule of law at the national and international levels and public participation/https://www.unodc.org/ documents/congress/Declaration/V150 4153_Russian.pdf (Date of application: 2021, January 26).
3. Constitution of the Republic of Uzbekistan - T.: «Uzbekistan» Publication House, 2020. P.67 (P.74).

4. Mikhaylov A.E., Tkachuk T.A., Butenko T.P. Problems of perception by the person conducting the preliminary investigation of the functions of crime prevention.- Bulletin AmSU. Volume 70, 2015

https://cyberleninka.ru/article/n/proble my-vospriyatiya-litsom-

osuschestvlyayuschim-predvaritelnoerassledovanie-funktsiy-po-profilaktikeprestupleniy (Date of application: 2021, February 10).

5. Preliminary investigation: Textbook for the Academy of the MIA: revised and supplemented third edition / A. X. Rakhmonkulov, D. M. Mirazov, A. O. Sharafutdinov and others. - T.: Academy of the MIA of the Republic of Uzbekistan, 2019. Pp. 484-485 (P.665).

6. Decree of the President of the Republic of Uzbekistan "On measures to radically improve the system of criminal and criminal procedural legislation" dated on May 14, 2018, PD3723/ https://lex.uz/docs/3735818 (Date of application: 2021, February 13).

7. Decree of the President of the Republic of Uzbekistan dated on March 14, 2017, PD-2833 "On measures to further improve the system of crime prevention and fight against crime" / https://nrm.uz/contentf?doc $=495100$ (Date of application: 2021, February 13).

8. Resolution of the Cabinet of Ministers of the Republic of Uzbekistan dated on January 8, 2018, №15 “On approval of the Regulation on the procedure for incentives of citizens and public 
Doi: https://doi.org/10.37547/tajpslc/Volume03Issue03-09

organizations for active participation in crime prevention and fight against crime" / https://lex.uz/docs/3499747 (Date of application: 2021, February 13).

9. Resolution of the Plenum of the Supreme Court dated on December 19, 2020, №34 "On increasing the role of courts in determining the causes of crime and the conditions that led to their commission" / https://lex.uz/docs/5208203 (Date of application: 2021, February 12).

10. Saidov B.A. Umarxonov Sh.A. The principles of crime process: Manual. T.: Academy of the MIA of the Republic of Uzbekistan, 2010. P.144 (P.192).

11. Application of the President of the Republic of Uzbekistan Shavkat Mirziyoyev to the Oliy Majlis / https://uza.uz/uz/posts/zbekistonrespublikasi-prezidenti-shavkatmirziyeevning-oliy-25-01-2020 (Date of application: 2021, February 13). 